\title{
REMARKS ON THE TRUNK-SHIELD STRUCTURE IN HOMOSTIUS (PLACODERMI)
}

\author{
Elga MARK-KURIK
}

Eesti Teaduste Akadeemia Geoloogia Instituut (Institute of Geology, Estonian Academy of Sciences), Estonia pst. 7, EE-0100 Tallinn, Eesti (Estonia)

Presented by D. Kaljo

Received March 17, 1993; accepted May 28, 1993

\begin{abstract}
The posterior lateral plate, a small but independent element in the trunkshield of the Middle Devonian arthrodire Homostius, is described in detail for the first time. Earlier the plate was believed to be missing in this arthrodire. The posterior lateral plate has preserved in two different ways: it occurs either separately being interlocked with the adjacent plates (anterior lateral, anterior dorsolateral, and posterior dorsolateral) in an articulated trunk-shield or is more or less fused to the anterior dorsolateral plate. Morphologically the posterior lateral plate is rather similar to the equivalent element in the Late Devonian Eastmanosteus calliaspis Dennis-Bryan. Also the trunk-shield of Homostius with a large pectoral embayment resembles that of $E$. calliaspis, though in the former the posterior ventral plates are lacking, and the shield is much flatter.
\end{abstract}

Key words: morphology, Arthrodira, Placodermi, Middle Devonian, Estonia.

Homostius is a large specialized arthrodire (Placodermi) characterized by a flat skull and anterior part of the body, elongated nuchal portion of the skull-roof, and a short trunk-shield lacking posterior ventral elements. It occurs frequently in the Middle Devonian of the Baltic and the adjacent areas, but is also known from Scotland, Greenland, Spitsbergen, and, probably, from Severnaya Zemlya. Homostius was thoroughly described by Heintz in his monograph of 1934, based mainly on the rich collection of isolated bones from the Aruküla caves near Tartu, Estonia. Heintz also studied the Scottish material, consisting of articulated specimens.

\section{PLATE I}

Lateral trunk-shield plates of Homostius latus Asm. Figs. 1, 2. The right PL plate, Pi 622; 1 - external view, 2 - visceral view. Fig. 3. Anterior portion of the right PDL plate, Pi 620. Fig. 4. A fragment of the left ADL plate with an attached PL plate of a comparatively young individual, $\mathrm{Pi} 030$. Fig. 5. The left ADL plate with a completely fused $\mathrm{PL}$ plate, $\mathrm{Pi}$ 597. Fig. 6. A fragment of the right ADL plate with the PL plate/attached to it, Asm 193. Pi 622, 620,030, and 597 come from the Karksi locality, Estonia, Middle Devonian, Givetian, Burtnieki Stage; Asm 193 from the Aruküla caves near Tartu, Estonia, Middle Devonian, Eifelian, Aruküla Stage.

ADL - anterior dorsolateral plate; AL.oa, PL.oa - overlapping areas for the anterior and posterior lateral plates, respectively; PDL - posterior dorsolateral, PL posterior lateral plates; th.a - thickening in the anterior end of the PL plate. Scale bars $=1 \mathrm{~cm}$. 


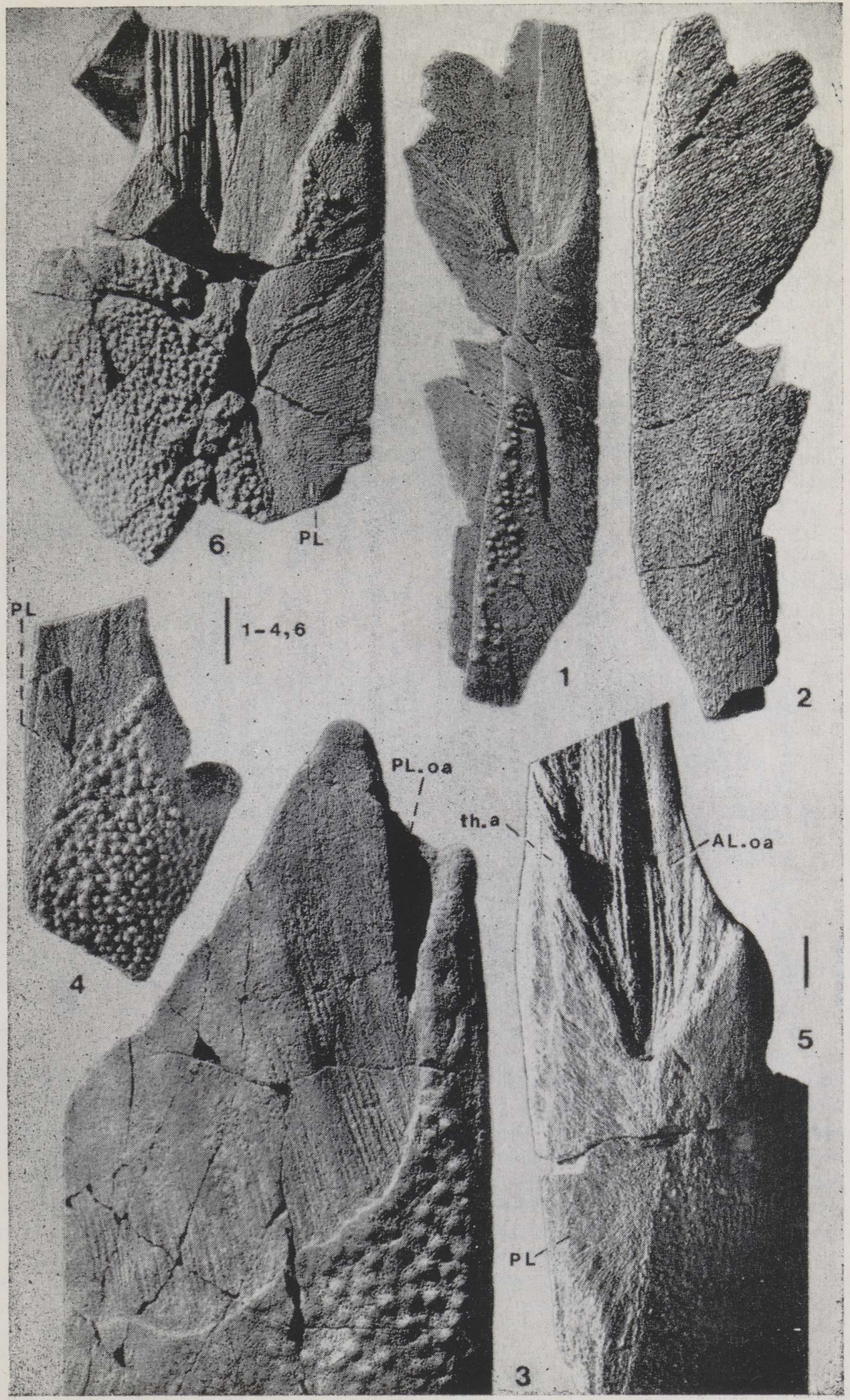




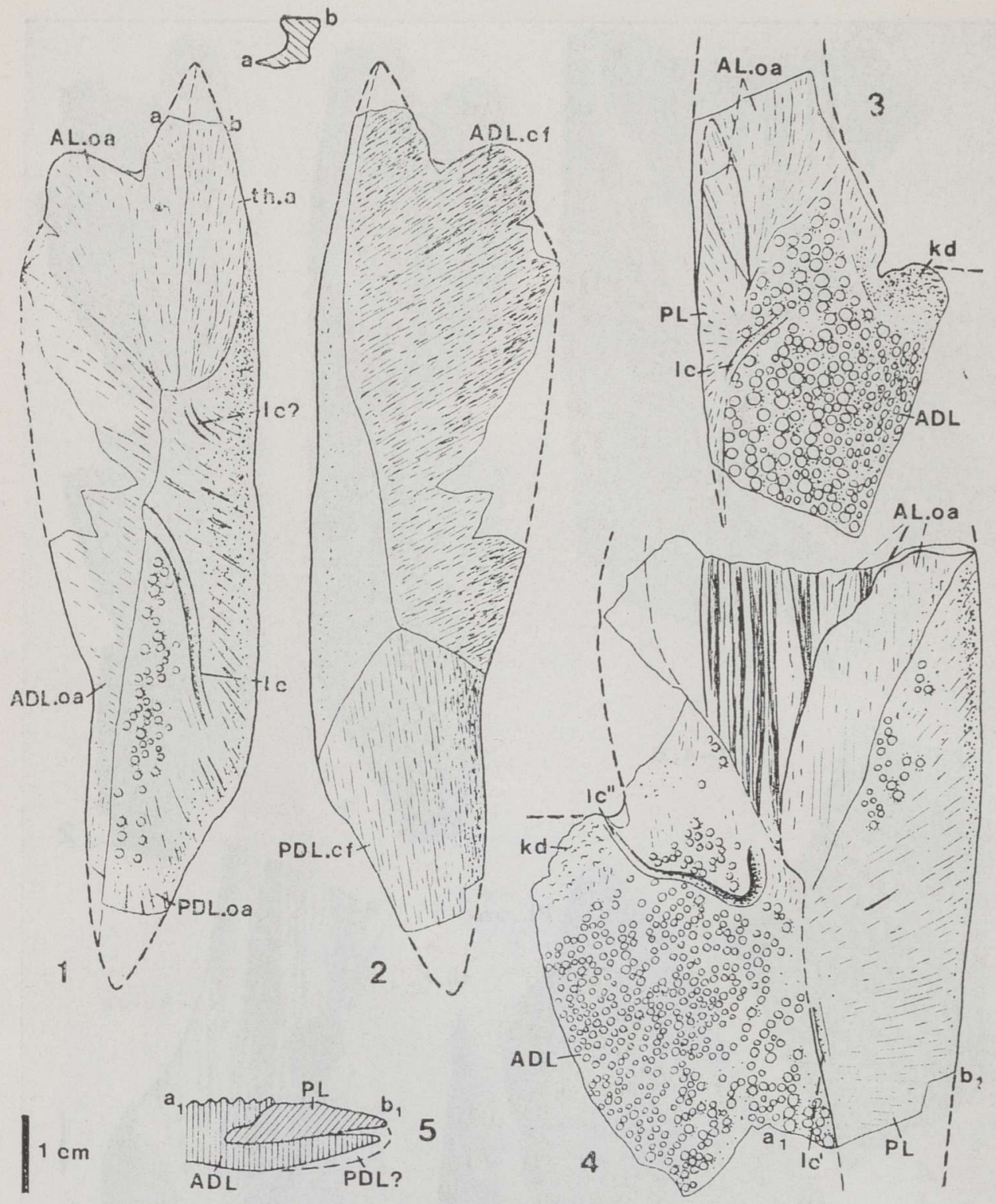

PLATE II

Posterior lateral (PL) plates of Homostius. Figs. 1, 2. Right PL, Pi 622; 1 - external view, 2 - visceral view. Fig. 3. Left PL fused to the anterior dorsolateral (ADL) plate, $\mathrm{Pi} 030$ belonging to a younger individual. Figs. 4, 5. Right PL attached to the ADL plate, Asm 193; 5 - cross-section at the posterolateral angle of the fragment. $\mathrm{ADL}, \mathrm{PDL}, \mathrm{PL}$ - anterior dorsolateral, posterior dorsolateral, and posterior lateral plates; ADL.cf, PDL.cf, ADL.oa, AL.oa - contact faces and overlapping areas for ADL, PDL, and $\mathrm{AL}$, respectively; $\mathrm{kd}$ - glenoid condyle; $1 \mathrm{c}, 1 \mathrm{c}$ ?, $1 \mathrm{c}^{\prime}, 1 \mathrm{c}^{\prime \prime}$ - grooves for main lateral line; th.a - thickening of the PL plate. 
Still, several details in the structure of Homostius needed further study, particularly those of the lateral part of the trunk-shield. Two small but significant elements of this shield, the spinal (Sp) and posterior lateral (PL) plates were discovered by the present author from another Estonian locality, Karksi. A description of the spinal plate and a new restoration of Homostius in lateral view showing the position of $\mathrm{Sp}$ and PL plates were given $(\mathrm{Mapk}, 1963)$. The restoration was critically revised by Heintz (1968), who denied the existence of the PL plate in this fish, and so did Denison (1978) following Heintz. It is understandable as the plate was only schematically figured (Марк, 1963, Fig. 7A). The Aruküla collection did not contain isolated PL plates, and the Scottish specimens did not show them either. The mostly small fragments of this plate fused to the anterior dorsolateral plates that were found in the Aruküla locality were also hardly noticed. As the PL plate is often insufficiently known in arthrodires, including the other members of the family Homostiidae, it is worth describing this plate in detail. Moreover, Homostius reveals a specific variant of the arthrodire trunk-shield in which the pectoral embayment is large and PL plates suture only with the dorsal trunk-shield plates, and the posterior ventral elements of the ventral armour are lacking (this is rare in arthrodires).

The material described in this paper belongs to Homostius latus Asm., and is housed in the collections of the Institute of Geology, Estonian Academy of Sciences (with indices Pi and Asm).

The specimen Pi 622 from the Karksi locality (P1. I, figs. 1, 2; Pl. II, figs. 1, 2) is the only PL plate of Homostius found separately. This slender and flat plate is largely occupied by the contact faces and overlapping areas for the adjacent plates. On the external surface a narrow somewhat ornamented lateral area was exposed. A slightly sinuous groove of the main lateral line (lc) runs back to the convex posterolateral angle. Anteriorly there seems to occur an additional sensory line groove (lc?). The radiation centre of the plate is located between these grooves. There is an anterior overlapping area for the anterior lateral plate (AL.oa). A thickening (th.a) runs parallel to the lateral margin of the anterior triangular area of the PL plate. The mesially situated area is overlapped and underlapped by the lateral edge of the anterior dorsolateral plate (ADL.oa); thus, the mesial margin of the PL plate forms a tongue-and-groove connection with the ADL plate. The posterior spine-like process of the PL plate was housed in a deep incision in the anterior end of the posterior dorsolateral (PDL) plate (Pl. I, fig. 3 , PL.oa). On the visceral surface there are a very narrow free area and two rough contact faces, the larger one for the ADL plate (ADL.cf) and the smaller one for the PDL plate (PDL.cf).

Two more specimens from Karksi, Pi 030 and 597 (Pl. I, figs. 4, 5; Pl. II, fig. 3) represent the PL plates that are fused to the ADL plates to a different degree. Both these PL plates are without any ornamentation. In $\mathrm{Pi}$ 030, which belongs to a comparatively young individual, the margins of the PL plate are clearly visible except in the mesial area where the PL plate fits with its margin into the groove in the edge of the ADL plate. Here the sensory line groove crosses the contact line of both plates. The other specimen, $\mathrm{Pi} 597$ ( $\mathrm{Pl}$. I, fig. 5), is a PL plate which is completely fused to the ADL plate. Only a shallow groove marks its anterior and lateral edges. The anterior thickening (th.a) can 
also be traced. The occurrence of the PL plate either separately or in contact with the ADL plate seems to depend purely on the individual's growth. Judging by the rather numerous ADL plates from Karksi with no PL plate on them, the first case is more common.

The same can be said on the basis of the collection from the Aruküla locality. In this collection the PL plates are, in most cases, preserved as small fragments in the slit along the lateral margin of the ADL plates of different size, e.g. in specimens Asm 3 (Heintz, 1934; P1. XVIII, figs. 3, 4), Asm 207, 223, 314, and 318. In the ADL specimen Asm 315 a fragment of the anterior end of the PL plate is fused to the AL overlapping area. Asm 317, a very large left ADL plate, reveals a PL plate that is as completely fused to the ADL as in the specimen Pi 597 from Karksi. The best preserved specimen of the PL plate occurs on a large fragment of the ADL plate, Asm 193 (Pl. I, fig. 6; Pl. II, figs. 4, 5). In comparison with the specimen Pi 622, the PL plate is narrower anteriorly. The external surface bears some tubercles near the overlapping area for the AL plate (Al.oa). A short groove of the main lateral line $\left(1 \mathrm{c}^{\prime}\right)$ runs parallel to the contact line with the ADL plate. The latter has another short and deep sensory line groove $\left(1 \mathrm{c}^{\prime \prime}\right)$ running in an unusual way. It starts at the glenoid condyle (kd) and curves in its lateral end abruptly toward the AL overlapping area (AL.oa). At the broken posterior edge of the fragment the interlock of the PL and ADL plates can be observed in cross-section (Pl. II, fig. 5). The very anterior end of the PDL plate might also participate in the complicated suture of the plates. As to the younger individuals, the sutures between the PL and the adjacent plates were evidently simpler. For example, the PDL plate of a small individual, Pi 936, from Karksi shows no incision meeting the PL plate as in specimen Pi 620 (Pl. I, fig. 3) from the same locality. In the Early Devonian homostiid Antineosteus lehmani the PL overlapping area in the PDL plate is also fairly simple (Lelièvre, 1984).

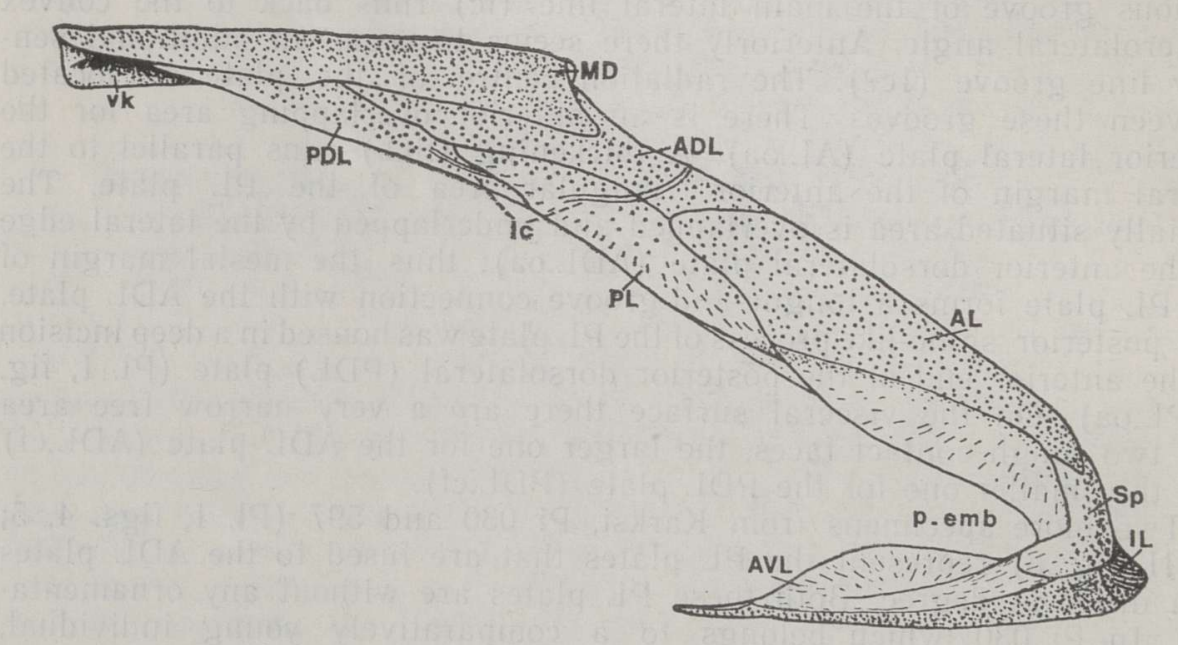

Trunk-shield of Homostius in lateral view (modified after Mapк, 1963).

$\mathrm{AL}, \mathrm{AVL}, \mathrm{IL}, \mathrm{MD}, \mathrm{Sp}$ - anterior lateral, anterior ventrolateral, interolateral, median dorsal, and spinal plates; p.emb - pectoral embayment; vk - ventral keel. For other abbreviations see Pl. II. 
The position of the PL plate in the trunk-shield is given in the Figure. Being firmly interlocked with the adjacent plates and sometimes forming a compound plate with the ADL, the PL plate strengthened the margin of the trunk-shield. A similar structure was described in a Late Devonian eastmanosteid, Eastmanosteus calliaspis by Dennis-Bryan (1987), who indicated that in this arthrodire only a small percentage of the PL plate was exposed in the articulated trunk-shield. Still, earlier the same kind of structure had been described and figured in Dunkleosteus (Dinichthys) by Heintz (1932). Homostius differs from the Late Devonian arthrodires mentioned above in a very weakly arched median dorsal (MD) plate. Therefore, in the lateral aspect the ADL and PDL plates as adjacent to the MD plate are strongly foreshortened so that the glenoid condyle of the ADL plate is not visible. The PL plate, being in contact with the downbent lateral edge of the ADL plate, is faced almost laterally.

\title{
ACKNOWLEDGEMENTS
}

I am grateful to D. Kaljo for critically reading the manuscript and to A. Noor for linguistic help.

\section{REFERENCES}

Denison, R. H. 1978. Placodermi. - In: Schultze, H.-P. (ed.). Handbook of Paleoichthyology, 2. Gustav Fischer Verlag, Stuttgart and New York.

Dennis-Bryan, K. 1987. A new species of eastmanosteid arthrodire (Pisces: Placodermi) from Gogo, Western Australia. - Zool. J. Linn. Soc., 90, 1-64.

Heintz, A. 1932. The structure of Dinichthys. A contribution to our knowledge of the Arthrodira. - Bashford Dean Memorial Volume - Archaic Fishes, 4, 115-224.

Heintz, A. 1934. Revision of the Estonian Arthrodira. Part I. Family Homostiidae Jaekel. - Archiv Naturk. Estlands, (I), 10, (4), 180-290.

Heintz, A. 1968. The spinal plate in Homostius and Dunkleosteus. - In: Orvig, T. (ed.). Current Problems of Lower Vertebrate Phylogeny. Almqvist and Wiksell, Stockholm, 146-151.

Lelièvre, H. 1984. Antineosteus lehmani n.g., n.sp., nuoveau Brachythoraci du Dévonien inférieur du Maroc présaharien. - Ann. Paléont., 70, 115-158.

Марк Э. Ю. 1963. О спинальной кости (spinale) среднедевонской артродиры Homostius. - Тр. Ин-та геол. АН ЭстССР, XIII, 189-200.

\section{MÄRKMED HOMOSTIUS'E (PLACODERMI) KEHARÜU EHITUSE KOHTA}

\author{
Elga MARK-KURIK
}

Uksikasjalikult on kirjeldatud keskdevoni artrodiiri Homostius'e tagumist lateraalplaati, mis kõvendas keharüü külgmist serva. Seesuguseid plaate võib leida nii üksikult kui ka eesmise dorsolateraalplaadiga kokkukasvanult. Homostius'e keharüü (joon.) oli üsna iseäralik. See oli väga lame ja külje poolt avatud (avauses paiknes rinnauime sisetoes). Rüü kõhtmine osa oli lühike (tagumised plaadid puudusid). 


\section{ЗАМЕЧАНИЯ О СТРОЕНИИ ТУЛОВИЩНОГО ПАНЦИРЯ HOMOSTIUS (PLACODERMI)}

\section{Эльга МАРК-КУРИК}

В статье детально описана задняя боковая пластинка (PL) среднедевонской артродиры Homostius. Эта пластинка встречается либо в изолированном, либо в сросшемся с передней спинно-боковой пластинкой (ADL) виде. Туловищный панцирь Homostius весьма своеобразен (рисунок) - он плоский, сбоку открытый (в вырезке помещался эндоскелет грудного плавника), брюшная часть короткая. 